\title{
Performance Evaluation of Ethanol-Diesel Blend in Compression-Ignition Engine
}

\section{Yahuza I**, Dandakouta $\mathrm{H}^{2}$ and Ibrahim $\mathrm{ME}^{3}$}

${ }^{1}$ Department of Automobile Engineering, Abubakar Tafawa Balewa University, Bauchi, Nigeria

${ }^{2}$ Department of Mechanical/Production Engineering, Abubakar Tafawa Balewa University, Bauchi, Nigeria

${ }^{3}$ Department of Mechanical Engineering, Federal University of Technology, Yola, Nigeria

\begin{abstract}
Ethanol was produced from saw dust of Masonia wood by means of simultaneous saccharification and fermentation process. The Ethanol produced was blended with Diesel in different proportions. The fuel properties of the Ethanol-Diesel (ED) blends at different temperatures and load conditions were experimentally investigated. The properties determined were relative density, cloud point, pour point, flash point, viscosity and the calorific value. The Diesel Engine Test Bed (Petter: PJ2W-type, 7227/22.5 BS) was used with ED blends having 5, 10, 15 and 20\% ethanol with respectively $95,90,85$ and $80 \%$ diesel on a volume basis to know the performance of the blends. The experimental results of the engine's performance which include the brake power, brake specific fuel consumption, brake thermal efficiency for the fuel blends were analyzed to know the suitability of using ED blend in Compression Ignition engine. The results show that both the relative density and viscosity of the blends decreased as the ethanol content in the blends was increased. All the blends were found to have the same cloud point of $5^{\circ} \mathrm{C}$ with that of diesel while their pour points vary and differ from that of diesel. All the blends have flash points $65 \%$ lower than that of diesel. The calorific values for ED5, ED10, ED15 and ED20 blends were 2, 3, 4 and 6\% respectively less than that of diesel. The engine's performance analysis indicated that there was an increase in brake thermal efficiency of the engine with increased proportion of ethanol in the fuel blends. The ED20 gave higher brake thermal efficiency than the diesel fuel at all load conditions. It was observed that at all loads conditions; the mass flow rate of ED20 was low so, resulting in decreased in specific fuel consumption. At all loads conditions, carbon dioxide emissions increased while hydrocarbon emissions decreased with increased amount of ethanol in the fuel blends, with ED20 showing the least emissions levels. Also, at all loads conditions, $\mathrm{NO}_{\mathrm{x}}$ emission of the blends was found to be higher than that of standard diesel due to the oxygen concentration and combustion timing. The results found showed that the ED20 ( $20 \%$ ethanol and $80 \%$ diesel) can be used in $\mathrm{Cl}$ engine without any modification.
\end{abstract}

Keywords: Ethanol; Masonia; Fermentation; Blend; Diesel engine

\section{Introduction}

The continuous rise in petroleum price, increasing threat to the environment from exhaust emissions from engines run on petroleum fuels and global warming have generated an intense international interest in developing alternative non-petroleum fuels for engines. Ethanol has been identified as one of the possible alternative fuels [1]. Ethanol can be produced from crops with high sugar or starch contents. Some of these crops include; sugarcane, sorghum, corn, barley, cassava, sugar-beets, etc. Besides being a biomass based renewable fuel, ethanol has cleaner burning and higher octane rating than the various vegetable oils [2]. Gasohol (a mixture of 10\% alcohol with $90 \%$ gasoline) is already a commercial fuel in over 35 countries of the World including the USA, Canada and France. In Brazil, cars with modified engines have been running for years on neat alcohol.

The use of ethanol blended with diesel was a subject of research in the 1980s and it was shown that ethanol-diesel blends were technically acceptable for the existing diesel engines. The relatively high cost of ethanol production at that time meant that the fuel could only be considered in cases of fuel shortages. Recently, the economics have become much more favorable in the production of ethanol and it is able to compete with standard diesel. Consequently, there has been renewed interest in the ethanol-diesel blends with particular emphasis on emissions reductions. An additional factor that makes ethanol attractive as a fuel substitute is that it is a renewable resource. The dwindling fossil fuel sources and the increasing dependency of the USA on imported crude oil have led to a major interest in expanding the use of bioenergy [3]. The commitment by the USA government to increase bioenergy three-fold in 10 years has added impetus to the search for viable biofuels [4]. The European Union (EU) has also adopted a proposal for a directive on the promotion of the use of biofuels with measures ensuring that biofuels account for at least $2 \%$ of the market for gasoline and diesel sold as transport fuel by the end of 2005, increasing in stages to a minimum of $5.75 \%$ by the end of 2010 [3].

Wood is a complex of natural organic polymer substances that include cellulose, hemicelluloses and lignin. Cellulose is a structural polysaccharide and consists of long chains of D-glucose units linked by $\beta-1,4$ glycosidic bonds. Hemicelluloses are built up from a relatively limited number of sugar residues that include D-xylose, D-mannose, D-glucose, D-galactose, L-Arabinose, 4-O-methyl-D-glucuronic acid, D galacturonic acid, D-glucuronic acid and to a lesser extent, L-Rhamnose, L-fructose and various O-methylated neutral sugars [5]. Lignin is made up of three primary precursors which include trans-coniferyl, transsinapyl and trans-p-coumaryl alcohols [6]. Lack of enzymic control during lignin polymerization results in an almost random series of bonding and a very complex structure [7]. The

*Corresponding author: Yahuza Ibrahim, Department of Automobile Engineering Abubakar Tafawa Balewa University, Bauchi, Nigeria, Tel: 234-803-690-7285; E-mail: ibnyahuza@yahoo.com

Received November 05, 2015; Accepted April 25, 2016; Published April 29, 2016

Citation: Yahuza I, Dandakouta H, Ibrahim ME (2016) Performance Evaluation of Ethanol-Diesel Blend in Compression-Ignition Engine. J Bioprocess Biotech 6: 281 doi:10.4172/2155-9821.1000281

Copyright: $\odot 2016$ Yahuza I, et al. This is an open-access article distributed under the terms of the Creative Commons Attribution License, which permits unrestricted use, distribution, and reproduction in any medium, provided the original author and source are credited. 
existence of strong carbon-carbon (CC) and ether (C-O-C) linkages in the lignin affects its susceptibility to chemical disruption [8]. The non-structural components of wood include extractives which consist of triglycerides, fatty acids, waxes, fatty alcohols, sterols and steryl esters [9].

\section{Aim and objectives of the research}

The aim of this work is to produce ethanol from sawdust of Masonia wood using Simultaneous Saccharification and Fermentation (SSF) process and the specific objectives to be realized in this work are:

- to blend the ethanol produced with pure diesel in different proportions;

- to investigate the physico-chemical properties of the ethanol-diesel blends; and

- to conduct tests on engine performance on a diesel engine test bed using different ethanol-diesel blends. The tests would include the torque, exhaust gas temperature, engine brake power, brake specific fuel consumption, and brake thermal efficiency.

\section{Methodology}

The research work was carried out as follows:

A. Production of ethanol using sawdust of Masonia wood by fermentation method and characterization of the ethanol.

B. Blending of the ethanol with diesel in various proportions.

C. Performance analyses of the blends on a diesel test bed.

The production of the ethanol was carried out as follows:

\section{Collection of the material and conversion process}

The sawdust was obtained from wood market of Muda Lawal, Bauchi, Nigeria, which was the major raw material used for the production of the ethanol. The material was collected in sack and transported to the Chemistry Laboratory of Abubakar Tafawa Balewa University, Bauchi, where the production was carried out.

The sawdust collected was sieved to create uniformity of particles. The sawdust was then dried for 12 hours under the sun to remove moisture. A big glass beaker of $7500 \mathrm{ml}$ was filled with $2500 \mathrm{~g}$ of dry sawdust and $2500 \mathrm{ml}$ of $18 \mathrm{M} \mathrm{H}_{2} \mathrm{SO}_{4}$ (sawdust to acid (w/v) ratio is 1:1) was added to it at ambient temperature of $28^{\circ} \mathrm{C}$. The reaction was spontaneous, producing lignin (lignin is the substance that bonds sugar molecules to make cellulose out of them) which was seen as black residues. The container also immediately became very hot and bubbles were formed due to air pockets in the sawdust. However, the $\mathrm{pH}$ was very low (about 1.18) and Saccharomyces cerevisiae could not function under this condition; it would function optimally at a $\mathrm{pH}$ of 4.5-6.0. Thus, there was need to increase the $\mathrm{pH}$. This was achieved by adding $2000 \mathrm{ml}$ of water at a $\mathrm{pH}$ of 9.7 into the acidic solution contained in a $10000 \mathrm{ml}$ beaker and the mixture was stirred thoroughly. The $\mathrm{pH}$ was read to be 1.37. In order to increase the $\mathrm{pH}$ value further, $1000 \mathrm{ml}$ of water was added again to the solution and stirred thoroughly; the $\mathrm{pH}$ was then read to be 1.91 . Furthermore, $1000 \mathrm{ml}$ of water was added to the solution and the $\mathrm{pH}$ increased to 2.35 . However, the allowable dilution factor with water is $1: 4$ and even if the water was added for the fourth time, the required $\mathrm{pH}$ value will not be attained. Therefore, to raise the $\mathrm{pH}$ to the required value necessitated the use of sodium hydroxide $(\mathrm{NaOH})$. From Equation 1, it can be seen that $9 \mathrm{M} \mathrm{NaOH}$ is required to form salt ( $\mathrm{pH}: 7)$ and less will be required for an optimal reaction (i.e., $\mathrm{pH}$ of 4.5 to 6.0 )

$$
\mathrm{H}_{2} \mathrm{SO}_{4}+2 \mathrm{NaOH} \rightarrow \mathrm{Na}_{2} \mathrm{SO}_{4}+2 \mathrm{H}_{2} \mathrm{O}
$$

A solution of $8.5 \mathrm{M} \mathrm{NaOH}$ was prepared and added drop by drop until a $\mathrm{pH}$ value of 4.87 was attained. The solution was filtered bringing out the cellulose substrate as filtrate and lignin as residue using a Buchner funnel. Using a DMA-35 meter, the sugar produced was measured to be $920.4 \mathrm{~g}$

\section{Fermentation and distillation}

The cultures of Saccharomyces cerevisiae in an agar slant tubes were dissolved with $100 \mathrm{ml}$ of distilled water containing a drop of tween $80.1000 \mathrm{ml}$ of the solution was then added to the cellulose substrate to ferment it. On a four-hourly basis, the sample was tested for sugar content to determine the rate of conversion of sugar to ethanol, thereby determining the time required for fermentation and the rate of fermentation. Ethanol fermentation was performed in a shaker incubator at $150 \mathrm{rpm}$ for $0-60$ hours at $30^{\circ} \mathrm{C}$ to allow it to ferment completely. Bubbles of $\mathrm{CO}_{2}$ were seen to appear. The sugar concentrations in brix against time in hours are presented in Figure 1.

This $1000 \mathrm{ml}$ of the filtrate was then distilled using a distillation bath. $157.9 \mathrm{ml}$ of ethanol was distilled at $78^{\circ} \mathrm{C}$ and water was distilled at $100^{\circ} \mathrm{C}$. According to Jorgensen et al. [10], $52.2 \mathrm{~g}$ of sugar is present in $100 \mathrm{~g}$ of hardwood sawdust. Therefore, in $2500 \mathrm{~g}$ of hardwood there would be $1305 \mathrm{~g}$ of sugar.

Thus, the sugar yield is: Sugar Yield $=\frac{\text { Actual value }}{\text { Theoretical value }} \times 100 \%$

\section{Blending of the samples}

After obtaining the ethanol using the above mentioned steps, the ethanol-diesel blends were produced with (\%,v/v) 5, 10, 15 and 20 of ethanol with 95, 90, 85 and 80 of diesel, and the blends were labeled as DE5, DE10, DE15 and DE20 respectively. The following properties were determined for each of the samples produced:

(i) Relative density

(ii) Cloud point

(iii) Pour point;

(iv) Viscosity

(v) Calorific value

Engine tests were carried out in order to determine the following engine's performance parameters:

(i) brake power;

(ii) brake thermal efficiency; and

(iii) specific fuel consumption.

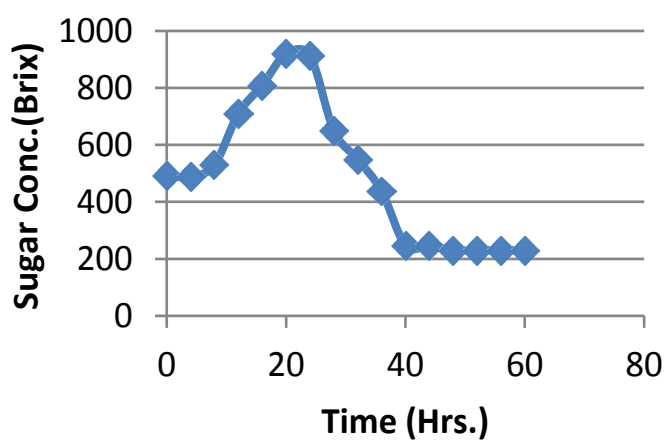

Figure 1: Sugar concentration (Brix) against time (Hrs.) for fermentation. 


\section{Experimental tests}

Laboratory tests were carried out using ASTM: D6079-04 standard test procedure to determine the properties of the blends.

Relative density: The relative density, otherwise known as the specific gravity refers to the ratio of the density of a fuel to the density of water at the same temperature [2]. The density of each of the fuel blends at three different temperatures was measured by means of a capillary stopper relative density bottle of $20 \mathrm{ml}$ capacity.

Cloud point: Cloud point is the temperature at which solidification of heavier components of a fuel resulting in a cloud of crystals within the body of the fuel first appear [2]. This temperature was determined for each of the fuel blends samples using Armfield Engineering Teaching and Research Equipment of cloud and pour point apparatus.

Pour point: The temperature at which on further cooling of fuel, results in increased size and number of wax crystals and eventual coalescence of the fuel to form a rigid structure is termed pour point. Cloud and pour points temperatures are of importance in knowing the behavior of fuels in a cold weather. Also, the pour point was determined using Armfield Engineering Teaching and Research Equipment of cloud and pour point apparatus (Table 1).

Flash point: This is the minimum temperature at which the vapor given off by a fuel when heated will flash when a test flame is held above the surface without the fuel catching fire; and it is of importance when determining the fire hazard (temperature at which fuel will give off inflammable vapor) (Table 2). Flash points of the samples were measured by Armfield Engineering Teaching and Research Equipment.

Viscosity: The resistance to flow exhibited by fuel blends, as expressed in various unit of viscosity, is a major factor of consequence in establishing their suitability for the mass transfer and metering requirements of engine operation. According to Ajav and Akingbehin

[2] the coefficient of viscosity $\eta$ is expressed as:

$$
\eta=\frac{\tau}{S}
$$

Where: $\eta=$ Dynamic viscosity, Pa.s

$\tau=$ Shear stress, $\mathrm{Pa}$

$\mathrm{S}=$ Shear rate, $\mathrm{s}^{-1}$

A U-tube Saybolt viscometer was used for measurement of the dynamic viscosity of the samples at the Department of Chemistry, Abubakar Tafawa Balewa University, Bauchi. The experiments were performed at $20^{\circ} \mathrm{C}, 25^{\circ} \mathrm{C}, 30^{\circ} \mathrm{C}, 35^{\circ} \mathrm{C}$, and $40^{\circ} \mathrm{C}$ and the tests were repeated three times. The apparatus was based on the principle of measuring the time of gravity flow (in seconds) of the sample through a specified hole. The dynamic viscosity was calculated from the time by the following formula [2]:

$$
\eta=0.07313 d t-5.94458 \frac{d}{t}
$$

Where: $\eta=$ Dynamic viscosity, $\mathrm{cP}$

$$
\mathrm{d}=\text { Density of sample, } \mathrm{g} / \mathrm{ml}
$$

$\mathrm{t}=$ Flow time, $\mathrm{s}$

Calorific value: The calorific values of the blends were determined with the help of a Gallenkamp ballistic bomb calorimeter. A known amount of fuel was burnt in this bomb calorimeter. The air was replaced by pure oxygen. The maximum deflection of the galvanometer on the control box was recorded after burning the samples. The effective heat capacity of the system was also determined using same procedure but with pure and dry benzoic acid as the test fuel. The calorific value was calculated as [2]:

CalorificValue $(C . V)=.\frac{\left(\mathbf{a}_{3}-\mathbf{a}_{1}\right) Y}{Z}$

Where: $\mathrm{C} . \mathrm{V}=$ Calorific value of sample, $\mathrm{kJ} / \mathrm{kg}$

$\mathrm{a}_{1}=$ Galvanometer deflection without sample

$\mathrm{a}_{3}=$ Galvanometer deflection with sample

$\mathrm{Y}=$ Calibration constant

$\mathrm{Z}=$ Mass of fuel sample, $\mathrm{g}$

The calibration constant $(\mathrm{Y})$ is given as:

$Y=\frac{6.32 \mathcal{W}_{1}}{a_{2}-a_{1}}$

Where:

$\mathrm{a}_{1}=$ Galvanometer deflection without sample

$\mathrm{W}_{1}=$ Mass of benzoic acid

$\mathrm{a}_{2}=$ Galvanometer deflection with benzoic acid.

\section{Engine tests for the performance of blends}

The tests were carried out on a 4-stroke, 1-cylinder, $1.0 \mathrm{~L}, 5.6 \mathrm{~kW}$ engine. The engine model is Petter: PJ2W-type, 7227/22.5 BS. The test engine specifications are given in Table 3.

The engine was coupled to an Eaton Dynamatic (model AD806) DG eddy current dynamometer rated at $5.6 \mathrm{~kW}$ at $1500 \mathrm{rpm}$. The dynamometer was controlled by a Digalog (model 1022A-STD) dynamometer controller. The flow rate of diesel fuel into the engine was measured with a Brooks (model BM01ARSPA2RVA) micro-oval flow meter. The volumetric flow rate of air inducted into the engine was measured with a Meriam laminar flow element (model 50MC2-4). The engine was operated at a speed of $1500 \mathrm{rpm}$. The same test protocol was used for each set of the blends.

\begin{tabular}{|c|c|c|c|}
\hline Statistics & World total & Weighted average & Highest country \\
\hline $\begin{array}{c}\text { Oil Reserves for } 89 \text { countries } \\
\text { (barrels) }\end{array}$ & $1,394,417,153,00$ & $13,911,517,041.2$ & Saudi Arabia with 262,700,000,000 \\
\hline $\begin{array}{c}\text { Oil Consumption for } 213 \\
\text { countries (barrels) }\end{array}$ & $85,085,664$ & $399,463.2$ & Ethiopia with 214,000 \\
\hline $\begin{array}{c}\text { Oil Exports (Net) for } 30 \text { countries, } \\
\text { in barrel/day }\end{array}$ & $32,234,418.5$ & $1,007,325.6$ & Niue with 20 \\
\hline $\begin{array}{c}\text { Oil Import (Net) for } 21 \text { countries, } \\
\text { in barrel/day }\end{array}$ & $29,916,829$ & $1,424,610.9$ & Bahrain with 15,000 \\
\hline Gasoline Prices & & $\$ 1.00 /$ liter & USA with $10,400,000$ \\
\hline
\end{tabular}

Source: CIA World Fact Book. 
Citation: Yahuza I, Dandakouta H, Ibrahim ME (2016) Performance Evaluation of Ethanol-Diesel Blend in Compression-Ignition Engine. J Bioprocess Biotech 6: 281. doi:10.4172/2155-9821.1000281

Page 4 of 7

\begin{tabular}{|c|c|c|c|}
\hline & $\%$ Cellulose & $\%$ Hemicellulose & $\%$ Lignin \\
\hline Hardwood & $40-55$ & $24-40$ & $18-25$ \\
\hline Softwood & $45-55$ & $25-35$ & $25-35$ \\
\hline
\end{tabular}

Source: Bailey and Ollis.

Table 2: Weight percent of cellulose, hemicelluloses and lignin in wood biomass.

\begin{tabular}{|c|c|}
\hline Parameters & Specifications \\
\hline Engine type & 4 -stroke diesel \\
\hline Number of cylinders & 1 \\
\hline Displacement & $1896 \mathrm{~cm}$ \\
\hline Bore stroke & $79.5 \times 95.5 \mathrm{~mm}$ \\
\hline Compression ratio & $12: 1$ to $17.5: 1$ \\
\hline Cooling method & Water cooled \\
\hline Valve configuration & OHC 2 valves/cylinder \\
\hline Injection pump & Bosh VE VP 37 \\
\hline Maximum output & $5.6 \mathrm{~kW}$ \\
\hline Rated speed & $1500 \mathrm{rpm}$ \\
\hline Maximum MEP & $1400 \mathrm{kPa}$ \\
\hline
\end{tabular}

Source: Petter: PJ2W-type, 7227/22.5 BS, 1997.

Table 3: Test Engine Characteristics.

Emissions of unburned hydrocarbons (HC) were measured using Beckman model 400A flame ionization detection (FID). Concentrations of $\mathrm{CO}$ and carbon dioxide $\left(\mathrm{CO}_{2}\right)$ were measured using Horiba (model PIR-2000) infra-red absorption gas analyzer. Oxides of nitrogen $\left(\mathrm{NO}_{\mathrm{x}}\right)$ were measured using Beckman model $450 \mathrm{~A}$ analyzer. The experimental set-up used to conduct the engine's performance tests is shown in Figure 2.

Brake power: The flywheel power is commonly referred to as brake power, $\mathrm{P}_{\mathrm{b}}$. The brake power was calculated using the following relation [11]:

$$
P_{b}=\frac{2 \pi T_{b} N_{e}}{60,000}
$$

Where: $T_{b}=$ engine brake torque, N.m

$$
\mathrm{N}_{\mathrm{e}} \text { = engine speed, rpm }
$$

Brake thermal efficiency: The brake thermal efficiency is the product of the indicated thermal efficiency and the mechanical efficiency. The indicated thermal efficiency is a measure of the combustion efficiency of the engine, while the mechanical efficiency indicates the efficiency in converting the indicated power to brake power. The indicated thermal and the mechanical efficiencies are defined respectively as follow [11]:

$$
\begin{aligned}
\eta_{i t} & =\frac{P_{i}}{P_{f e}} \\
\eta_{m} & =\frac{P_{b}}{P_{i}}
\end{aligned}
$$

Therefore, the brake thermal efficiency is given as:

$\eta_{b t}=\frac{P b}{P_{f e}}$

Where: $\mathrm{P}_{\mathrm{i}}=$ indicated power, $\mathrm{kW}$

$\mathrm{P}_{\mathrm{fe}}=$ fuel equivalent power,

$$
\begin{aligned}
& \mathrm{kW}=\frac{m_{f} H_{g}}{3600} \\
& \mathrm{~m}_{\mathrm{f}}=\text { fuel consumption rate, } \mathrm{kg} / \mathrm{h}
\end{aligned}
$$

$\mathrm{H}_{\mathrm{g}}=$ gross (higher) heating value of the fuel, $\mathrm{kJ} / \mathrm{kg}$

$\mathrm{P}_{\mathrm{b}}=$ brake (flywheel) power, $\mathrm{kW}$

$\mathrm{T}_{\mathrm{b}}=$ engine brake torque, $\mathrm{N} . \mathrm{m}$

$\mathrm{N}_{\mathrm{e}}$ = engine speed, rpm

$\mathrm{P}_{\mathrm{i}}=$ indicated power, $\mathrm{kW}$

Brake specific fuel consumption: Brake Specific Fuel Consumption (BSFC) indicates the amount of fuel consumed per unit of work (brake power) accomplished by the engine. The brake specific fuel consumption was calculated by dividing the fuel mass flow rate, $\mathrm{m}_{\mathrm{f}}$ by brake power. Mathematically,

$$
B S F C=\frac{m_{f}}{P_{b}}
$$

Where: $\mathrm{m}_{\mathrm{f}}=$ fuel consumption rate, $\mathrm{kg} / \mathrm{h}$

$\mathrm{P}_{\mathrm{b}}=$ brake (flywheel) power, $\mathrm{kW}$

\section{Results and Discussion}

\section{Physico-chemical analysis of the blends}

Percentage yield of ethanol: According to Jorgensen et al. [10], $52.2 \mathrm{~g}$ of sugar is present in $100 \mathrm{~g}$ of hardwood sawdust. Therefore, in $2500 \mathrm{~g}$ of hardwood there would be $1305 \mathrm{~g}$ of sugar.

Thus, the sugar yield is:

$$
\begin{aligned}
& \text { Sugar Yield }=\frac{\text { Actual value }}{\text { Theoretical value }} \times 100 \% \\
& \text { Sugar Yield }=\frac{920.4}{1305} \times 100 \%=70.53 \%
\end{aligned}
$$

Relative density: Table 4 shows the values of the relative densities of the blends at different temperatures, while Table 5 shows the percentage differences in the relative densities of the blends with that of diesel.

\begin{tabular}{|c|c|c|c|c|c|}
\hline $\begin{array}{c}\text { Fuel } \\
\text { sample }\end{array}$ & $\mathbf{2 0}^{\circ} \mathbf{C}$ & $\mathbf{2 5}^{\circ} \mathbf{C}$ & $\mathbf{3 0}^{\circ} \mathbf{C}$ & $\mathbf{3 5}^{\circ} \mathbf{C}$ & $\mathbf{4 0}^{\circ} \mathbf{C}$ \\
\hline Diesel & 0.8683 & 0.8637 & 0.8465 & 0.8339 & 0.8330 \\
\hline ED5 & 0.8510 & 0.8511 & 0.8320 & 0.8234 & 0.8205 \\
\hline ED10 & 0.8498 & 0.8467 & 0.8270 & 0.8219 & 0.8189 \\
\hline ED15 & 0.8388 & 0.8442 & 0.8261 & 0.8210 & 0.8143 \\
\hline ED20 & 0.8387 & 0.8421 & 0.8254 & 0.8200 & 0.8121 \\
\hline
\end{tabular}

Table 4: Relative density of the ethanol-diesel blends at different temperatures.

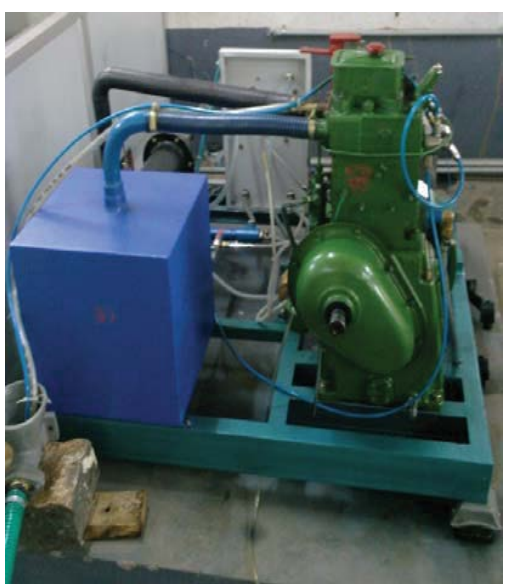

Figure 2: Diesel engine test bed. 
From Table 5 it can be seen that as the percentage of ethanol in the blends increases, the relative density decreases. This is an evidence that ethanol has lower density and as such will lower the density when mixed with diesel. It can also be seen that as the temperature increases, the relative density decreases for all the fuels. These findings compare with those earlier reported by Ajev and Akingbehim [2] and Hansen et al. [3].

Cloud point: The cloud points for the fuels are also presented in Table 6 . All the blends were found to have the same cloud point with that of diesel. The reason is that all the blends have diesel as a major component. Diesel was reported to have a cloud point of $5^{\circ} \mathrm{C}$ while ethanol below $100^{\circ} \mathrm{C}$ [3], therefore the cloud point found for all the blends was close to that of diesel.

Pour point: The presence of ethanol in the blends however affected the pour point. Fuel blends ED5, ED10, ED15 and ED20 were found to have pour point temperatures of $-6,-9,-13$ and $-38^{\circ} \mathrm{C}$, respectively (Table 7). This low temperature obtained for all the blends is due to the fact that ethanol delayed the degree of coalescence of the blends despite the high degree of miscibility of ethanol and diesel.

Flash point: From Table 8 it can be observed that all the blends have a flash point lower (over $65 \%$ lower) than that of diesel. The temperatures obtained were all below the ambient temperature of about $28^{\circ} \mathrm{C}$. Ethanol, which has a flash point below ambient temperature when blended with diesel that flashed at a temperature of $74^{\circ} \mathrm{C}$, vaporized and supplied the vapor that was ignited by the test flame. The flash point gives the safe storage temperature for the blends.

Viscosity: The measured viscosity of the blends decreased as the percentage of ethanol in the blends increased. The viscosities also decreased with increase in temperature. At $20^{\circ} \mathrm{C}$, the viscosities of ED5, ED10, ED15, ED20 blends were close to that of diesel (Table 9). The $20 \%$ blend was about $14 \%$ less viscous than diesel. The viscosities of the blends were however close to that of diesel when compared with other vegetable oils-diesel blends whose viscosities are usually very high $[7,9,12]$. The reduction in the viscosity of the blends was mainly due to the presence of ethanol (with a very low viscosity) in the blends.

Calorific value: The calorific values for the fuels are presented in Table 10. The calorific values for ED5, ED10, ED15 and ED20 blends were 2, 3, 4 and $6 \%$ respectively less than that of diesel. This indicates that the ethanol-diesel blends have over $90 \%$ of the calorific value of diesel. The calorific values decreased as the percentage of ethanol in the blends increased. When compared to other vegetable oils as reported

\begin{tabular}{|c|c|c|c|c|c|}
\hline Fuel sample & $\mathbf{2 0}^{\circ} \mathbf{C}$ & $\mathbf{2 5}^{\circ} \mathbf{C}$ & $\mathbf{3 0}^{\circ} \mathbf{C}$ & $\mathbf{3 5}^{\circ} \mathbf{C}$ & $\mathbf{4 0}^{\circ} \mathbf{C}$ \\
\hline Diesel & - & - & - & - & - \\
\hline ED5 & 1.73 & 1.26 & 1.45 & 1.05 & 1.25 \\
\hline ED10 & 1.85 & 1.70 & 1.95 & 1.20 & 1.41 \\
\hline ED15 & 2.95 & 1.95 & 2.04 & 1.29 & 1.87 \\
\hline ED20 & 2.96 & 2.16 & 2.11 & 1.39 & 2.09 \\
\hline
\end{tabular}

Table 5: Percentage deviation of relative densities of fuel blends from diesel.

\begin{tabular}{|c|c|}
\hline Fuel blend sample & Cloud Point $\left({ }^{\circ} \mathbf{C}\right)$ \\
\hline Diesel & 5 \\
\hline ED5 & 5 \\
\hline ED10 & 5 \\
\hline ED15 & 5 \\
\hline ED20 & 5 \\
\hline
\end{tabular}

Table 6: Cloud point of different blends.

\begin{tabular}{|c|c|}
\hline Fuel blend sample & Pour Point $\left({ }^{\circ} \mathbf{C}\right)$ \\
\hline Diesel & 5 \\
\hline ED5 & -6 \\
\hline ED10 & -9 \\
\hline ED15 & -13 \\
\hline ED20 & -38 \\
\hline
\end{tabular}

Table 7: Pour point of different blends.

\begin{tabular}{|c|c|}
\hline Fuel blend sample & Flash Point $\left.{ }^{\circ} \mathbf{C}\right)$ \\
\hline Diesel & 74 \\
\hline ED5 & 25 \\
\hline ED10 & 26 \\
\hline ED15 & 27 \\
\hline ED20 & 26 \\
\hline
\end{tabular}

Table 8: Flash point of different blends.

\begin{tabular}{|c|c|c|c|c|c|}
\hline $\begin{array}{c}\text { Fuel } \\
\text { sample }\end{array}$ & $\mathbf{2 0 ^ { \circ } \mathbf { C }}$ & $\mathbf{2 5}^{\circ} \mathbf{C}$ & $\mathbf{3 0}^{\circ} \mathbf{C}$ & $\mathbf{3 5}^{\circ} \mathbf{C}$ & $\mathbf{4 0}^{\circ} \mathbf{C}$ \\
\hline Diesel & 5.6114 & 4.7578 & 3.7863 & 3.4232 & 2.7652 \\
\hline ED5 & 5.5233 & 4.6701 & 3.6874 & 3.3241 & 2.6333 \\
\hline ED10 & 5.4614 & 4.3561 & 3.5535 & 3.2312 & 2.4521 \\
\hline ED15 & 5.2132 & 4.1002 & 3.4672 & 3.1231 & 2.3210 \\
\hline ED20 & 5.1011 & 3.8765 & 3.3895 & 2.6541 & 2.1974 \\
\hline
\end{tabular}

Table 9: Viscosity of the fuel blend samples at different temperatures

\begin{tabular}{|c|c|c|}
\hline Fuel sample & Calorific value (kJ/kg) & \%difference compared to diesel \\
\hline Diesel & 44514.6 & - \\
\hline ED5 & 43631.9 & 1.983 \\
\hline ED10 & 43192.5 & 2.970 \\
\hline ED15 & 42744.8 & 3.976 \\
\hline ED20 & 41874.5 & 5.931 \\
\hline & \multicolumn{2}{|c|}{ Table 10: Calorific value of the fuels. } \\
\hline
\end{tabular}

by Bansal and Juneja [9] and Masjuki et al. [13], the calorific values of the tested fuels were quite high which explains why ethanol-diesel blends have better combustion characteristics than other vegetable oils-diesel blends. The results of the current study on calorific values are similar to the ones earlier reported $[2,14,15]$.

\section{Engine's performance analysis}

The samples of $100 \%$ diesel, ED5, ED10, ED15 and ED20 were tested in the engine test bed at varying load of $500 \mathrm{~g}, 1000 \mathrm{~g}, 1500 \mathrm{~g}, 2000$ $\mathrm{g}$ and $2500 \mathrm{~g}$ to know the performance of the blends. Various values of torque, time taken to consume $7 \mathrm{ml}$ of fuel, exhaust temperature and air flow manometer readings were taken and tabulated as shown in Tables 11a-11e.

Brake power: The brake thermal efficiency and the brake specific fuel consumption of the blends were computed using excel spreadsheet. Figure 3 shows the variations of torque for the various blends while Figures 4-6 shows the variations of the performance characteristics under different loads conditions. Figure 3 shows linear increase in the torque of all the fuels from $500 \mathrm{~g}$ to $1500 \mathrm{~g}$ of loads [16,17]. After the $1500 \mathrm{~g}$ of load, there is decrease of the torque of all the fuels. The ED15 gave the higher torque from $1000 \mathrm{~g}$ to $2500 \mathrm{~g}$ of loads compared with the diesel, ED5, ED10 and ED20. At $2000 \mathrm{~g}$ and $2500 \mathrm{~g}$ of loads ED10 and diesel have the same torque while ED5, ED10 and ED20 are higher than the diesel. Figure 4 shows the variations of brake power for the blends at different load conditions. The ED20 gave the higher brake power at all load conditions than all the remaining fuels. At $2000 \mathrm{~g}$ of the load the diesel and the ED5 have the same value of the brake power while ED10 has lower value. At the full load (2500 


\begin{tabular}{|c|c|c|c|c|c|}
\hline $\begin{array}{c}\text { Load } \\
\mathbf{( g )}\end{array}$ & $\begin{array}{c}\text { Speed } \\
\mathbf{( r p m )}\end{array}$ & $\begin{array}{c}\text { Time taken } \\
\mathbf{( s )}\end{array}$ & $\begin{array}{c}\text { Torque } \\
\mathbf{( N m})\end{array}$ & $\begin{array}{c}\text { Exhaust } \\
\text { Temp. }\left(\mathbf{~}^{\circ} \mathbf{C}\right)\end{array}$ & $\begin{array}{c}\text { Air } \\
\text { pressure } \\
\left(\mathbf{m m} \mathbf{H}_{\mathbf{2}} \mathbf{0}\right)\end{array}$ \\
\hline 500 & 1500 & 32 & 18.21 & 301 & 35 \\
\hline 1000 & 1500 & 32 & 19.84 & 300 & 35 \\
\hline 1500 & 1500 & 35 & 20.96 & 304 & 35 \\
\hline 2000 & 1500 & 34 & 20.74 & 312 & 35 \\
\hline 2500 & 1500 & 36 & 20.68 & 311 & 35 \\
\hline
\end{tabular}

Table 11a: Engine performance for diesel fuel.

\begin{tabular}{|c|c|c|c|c|c|}
\hline $\begin{array}{c}\text { Load } \\
\mathbf{( g )}\end{array}$ & $\begin{array}{c}\text { Speed } \\
\mathbf{( r p m )}\end{array}$ & $\begin{array}{c}\text { Time taken } \\
\mathbf{( s )}\end{array}$ & $\begin{array}{c}\text { Torque } \\
\mathbf{( N m})\end{array}$ & $\begin{array}{c}\text { Exhaust } \\
\text { Temp. }\left(\mathbf{(}^{\circ} \mathbf{C}\right)\end{array}$ & $\begin{array}{c}\text { Air } \\
\text { pressure } \\
\left(\mathbf{m m} \mathbf{H}_{\mathbf{2}} \mathbf{0}\right)\end{array}$ \\
\hline 500 & 1500 & 27 & 18.25 & 300 & 35 \\
\hline 1000 & 1500 & 30 & 20.44 & 299 & 35 \\
\hline 1500 & 1500 & 31 & 20.79 & 301 & 35 \\
\hline 2000 & 1500 & 30 & 20.88 & 299 & 35 \\
\hline 2500 & 1500 & 29 & 20.78 & 298 & 35 \\
\hline
\end{tabular}

Table 11b: Engine performance for ED5.

\begin{tabular}{|c|c|c|c|c|c|}
\hline $\begin{array}{c}\text { Load } \\
\mathbf{( g )}\end{array}$ & $\begin{array}{c}\text { Speed } \\
\mathbf{( r p m )}\end{array}$ & $\begin{array}{c}\text { Time taken } \\
\mathbf{( s )}\end{array}$ & $\begin{array}{c}\text { Torque } \\
\mathbf{( N m )}\end{array}$ & $\begin{array}{c}\text { Exhaust } \\
\text { Temp. }\left(\mathbf{(}^{\circ} \mathbf{C}\right)\end{array}$ & $\begin{array}{c}\text { Air } \\
\text { pressure } \\
\left.\mathbf{( m m} \mathbf{H}_{\mathbf{2}} \mathbf{O}\right)\end{array}$ \\
\hline 500 & 1500 & 30 & 18.39 & 287 & 35 \\
\hline 1000 & 1500 & 32 & 20.54 & 288 & 35 \\
\hline 1500 & 1500 & 33 & 20.76 & 290 & 35 \\
\hline 2000 & 1500 & 30 & 20.74 & 293 & 35 \\
\hline 2500 & 1500 & 29 & 20.68 & 296 & 35 \\
\hline
\end{tabular}

Table 11c: Engine performance for ED10.

\begin{tabular}{|c|c|c|c|c|c|}
\hline $\begin{array}{c}\text { Load } \\
\mathbf{( g )}\end{array}$ & $\begin{array}{c}\text { Speed } \\
\mathbf{( r p m )}\end{array}$ & $\begin{array}{c}\text { Time taken } \\
\mathbf{( s )}\end{array}$ & $\begin{array}{c}\text { Torque } \\
\mathbf{( N m})\end{array}$ & $\begin{array}{c}\text { Exhaust } \\
\text { Temp. }\left(\mathbf{~}^{\circ} \mathbf{C}\right)\end{array}$ & $\begin{array}{c}\text { Air } \\
\text { pressure } \\
\left(\mathbf{m m} \mathbf{H}_{\mathbf{2}} \mathbf{0}\right)\end{array}$ \\
\hline 500 & 1500 & 34 & 18.82 & 289 & 35 \\
\hline 1000 & 1500 & 32 & 20.68 & 291 & 35 \\
\hline 1500 & 1500 & 30 & 21.28 & 293 & 35 \\
\hline 2000 & 1500 & 29 & 20.98 & 295 & 35 \\
\hline 2500 & 1500 & 31 & 21.03 & 298 & 35 \\
\hline
\end{tabular}

Table 11d: Engine performance for ED15.

\begin{tabular}{|c|c|c|c|c|c|}
\hline $\begin{array}{c}\text { Load } \\
\mathbf{( g )}\end{array}$ & $\begin{array}{c}\text { Speed } \\
\mathbf{( r p m )}\end{array}$ & $\begin{array}{c}\text { Time taken } \\
\mathbf{( s )}\end{array}$ & $\begin{array}{c}\text { Torque } \\
\mathbf{( N m})\end{array}$ & $\begin{array}{c}\text { Exhaust } \\
\text { Temp. }\left(\mathbf{(}^{\circ} \mathbf{C}\right)\end{array}$ & $\begin{array}{c}\text { Air } \\
\text { pressure } \\
\left(\mathbf{m m} \mathbf{H}_{\mathbf{2}} \mathbf{0}\right)\end{array}$ \\
\hline 500 & 1800 & 32 & 18.61 & 290 & 35 \\
\hline 1000 & 1800 & 30 & 20.74 & 289 & 35 \\
\hline 1500 & 1800 & 34 & 20.97 & 293 & 35 \\
\hline 2000 & 1800 & 35 & 20.84 & 297 & 35 \\
\hline 2500 & 1800 & 36 & 20.81 & 299 & 35 \\
\hline
\end{tabular}

Table 11e: Engine performance for ED20.

g) the diesel and the ED10 have the same value while ED15 has higher value than the diesel [18].

Brake thermal efficiency: Figure 5 shows the brake thermal efficiency of the test engine when run on the fuel blends under varying load conditions. There is an increase in brake thermal efficiency of the diesel and all the fuel blends at all the load conditions. The ED20 gave higher brake thermal efficiency at all load conditions as indicated in Figure 5. From $1500 \mathrm{~g}$ to $2500 \mathrm{~g}$ of loads, the brake thermal efficiencies of the ED5, ED10 and ED15 are lower than that of standard diesel. The ED5 gave the lowest brake thermal efficiency at $500 \mathrm{~g}$ of load. The brake thermal efficiency depends upon the combustion quality of the fuel; hence, ED20 blend gave better combustion quality than diesel.
Brake specific fuel consumption: The specific fuel consumption depends upon the mass flow rate. The brake specific fuel consumption is low for ED20 at all loads conditions, whereas for diesel, it is slightly high compared with the ED20. At low load condition, the specific fuel consumption of fuel blends ED10 and ED15 is lower than that of diesel [19]. At $1500 \mathrm{~g}, 2000 \mathrm{~g}$ and $2500 \mathrm{~g}$ of load conditions, the specific fuel consumption of the fuel blends ED5, ED10 and ED15 is higher than that of diesel fuel. It is also observed that specific fuel consumption decreases with the increase in load (Figure 6).

\section{Conclusion}

From the experimental investigation the following conclusions may be drawn:

1) Ethanol can be produced from saw dust of Masonia wood in reasonable quantity.

2) Relative densities at different temperature of all the blends are lower than that of diesel fuel.

3) All the blends were found to have the same cloud point with that of diesel. The reason is that all the blends have diesel as a major component.

4) All the blends have flash points that are over $65 \%$ lower than that of diesel. The temperatures obtained were all below ambient temperature of about $28^{\circ} \mathrm{C}$. Ethanol, which has a flash point below ambient when blended with diesel that flashes at a temperature of $74^{\circ} \mathrm{C}$, vaporizes and supplies the vapor that easily ignites. Hence, reducing ignition delay of the fuel blends when tested in an engine.

5) The viscosity decreased as the percentage of ethanol in the blends increased. The viscosities also decreased with increase in temperature. At $15^{\circ} \mathrm{C}$, the viscosities of $\mathrm{ED} 5, \mathrm{ED} 10, \mathrm{ED} 15, \mathrm{ED} 20$ blends were close to that of diesel. The ED20 blend is about $14 \%$ less viscous than diesel.

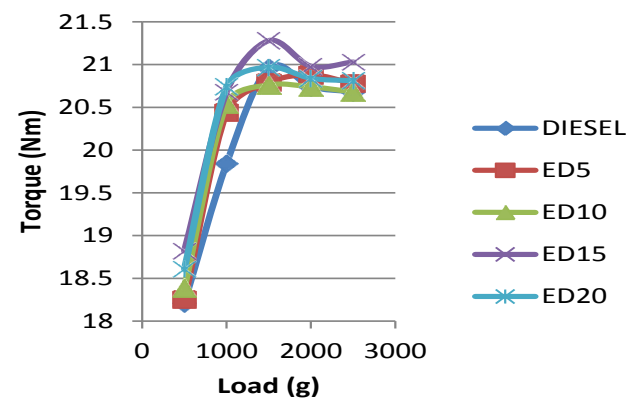

Figure 3: Variation of torque for the blends at different loads.

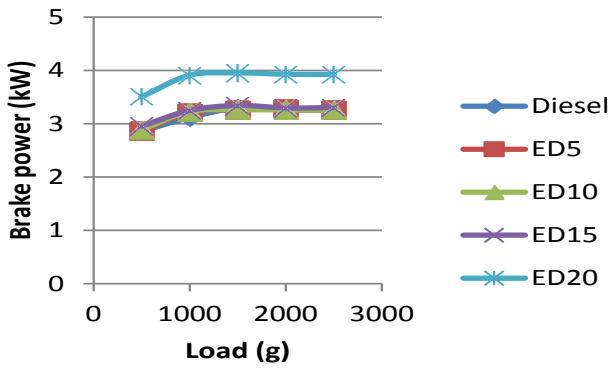

Figure 4: Variation of brake power for the blends at different loads. 


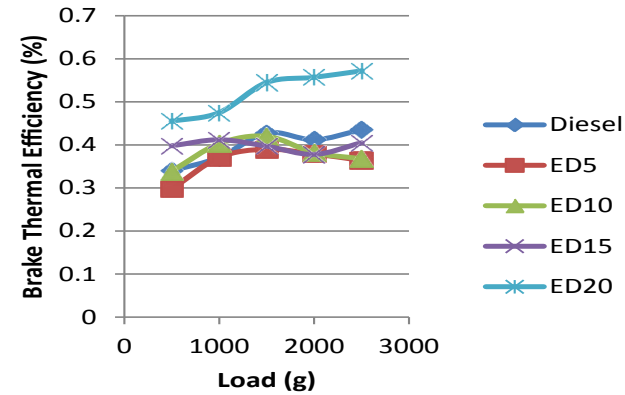

Figure 5: Variation of brake thermal efficiency for the blends at different loads.

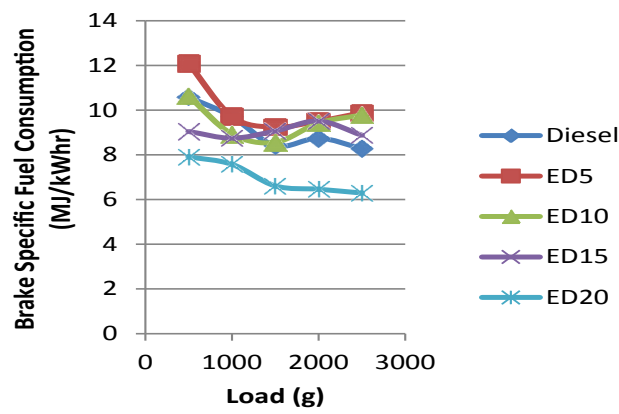

Figure 6: Variation of brake specific fuel consumption for the blends at different loads.

6) The calorific values for ED5, ED10, ED15 and ED20 blends were 2, 3, 4 and $6 \%$ respectively less than that of diesel. This indicates that the ethanol-diesel blends have over $90 \%$ of the calorific value of diesel.

7) There is an increase in brake thermal efficiency of the engine when run on all the fuel blends. The ED20 gave higher brake thermal efficiency than diesel fuel at all load conditions.

8) The mass flow rate is low for ED20 at all loads conditions; whereas for diesel, it is slightly high compared with the ED20. So, it leads to increase in specific fuel consumption of diesel.

9) Since all the blends have more oxygen content than diesel fuel, therefore, the blends may likely be involved in complete combustion process than the diesel. The maximum carbon monoxide emission was observed at $500 \mathrm{~g}$ of load when the engine was run on diesel fuel. ED20 gave low carbon monoxide emission than the other fuel blends at all load conditions.

10) The hydrocarbon emissions are lower with all the fuel blends than with standard diesel due to complete combustion process of the blends. When percentage of ethanol increases in the blends, hydrocarbon emission decreases. ED20 gave the lowest hydrocarbon emissions among all the fuel blends tested.

11) At all loads conditions, $\mathrm{NO}_{\mathrm{x}}$ emission of the blends is always higher than that of standard diesel due to the oxygen concentration and combustion timing. Since ethanol has very low cetane number, this causes increase in the $\mathrm{NO}_{\mathrm{x}}$ emission of the blends. The shorter ignition delay could be a reason of increased $\mathrm{NO}_{\mathrm{x}}$ emission.

\section{References}

1. Wrage KE, Goering CE (1977) Technical Feasibility of Diesohol. Transactions of the ASAE 23: 1338-1343.

2. Ajav EA, Akingbehin OA (2002) Biodegradability Characteristics of Current and Newly-Developed Alternative Fuels. SAE Technical Paper 1999-01-3518.
3. Hansen AC, Hornbaker RH, Zhang Q, Lyne PWL (2001) On-farm evaluation of diesel fuel oxygenated with ethanol. ASAE Paper No. 016173.

4. Biofuels Program (1998) Level of Green House Gas Emissions in Biofuels. U.S. Department of Energy.

5. Sjöström E (1993) Wood Chemistry: Fundamentals and Application. Academic Press. Orlando, USA, p: 293.

6. Argyropoulos DS, Jurasek L, Kristofová L, Xia Z, Sun Y, et al. (2002) Abundance and reactivity of dibenzodioxocins in softwood lignin. J Agric Food Chem 50: 658-666.

7. Msipa CKM, Goering CE, Karcher TD (1983) Vegetable oil Atomization in a DI Diesel Engine. Transactions of the ASAE 26: 1669-1672.

8. Karhunen P, Mikkola J, Pajunen A, Brunow G (1999) The behaviour of dibenzodioxocin structures in lignin during alkaline pulping processes. Nordic Pulp Paper Res J 14: 123-128.

9. Bansal BB, Juneja NN (1989) Performance evaluation of neem oil (Melia azadirachta) as diesel engine supplementary fuel. Proceedings of the 11 th international congress on agricultural engineering. 4: 2551-2556.

10. Jorgensen H, Kristensen JB, Felby C (2007) Enzymatic conversion of lignocellulose intofermentable sugars: challenges and opportunities. Biofuels, Bioprod Bioref 1: 119-134.

11. Goering CE, Stone ML, Smith DW, Turnquist PK (2003) Engine Performance Measures. In: Off-Road Vehicle Engineering Principles. American Society of Agricultural Engineers, pp: 19-36.

12. Varde KS (1984) Soy oil sprays and effects on engine performance. Transactions of the ASAE 27: 326-330.

13. Musjuki H, Abdulmuin MZ, Sii HS (1996) Investigations on Preheated Palm Oil Methyl Esters in the Diesel Engine. Proc Inst Mech Eng Part A: Journal of Power and Energy 210: 131-138.

14. Peterson C, Reece D (1996) Emissions Characteristics of ethyl and methy ester of Rapeseed oil compared with low sulfur diesel control fuel in a chassis dynamometer test of a pickup truck. Transactions of the ASAE 39: 805-816.

15. Ajav EA (1997) Studies on the use of ethanol-diesel blends and fumigated ethanol in a stationary constant speed compression-ignition engine. PhD Thesis. Department of Farm Machinery and Power Engineering, GBPUA \& T, Pantnagar, India.

16. de Caro PS, Mouloungui Z, Vaitilingom G, Berge JCh (2004) Interest of combining an additive with diesel-ethanol blends for use in diesel engines. Fuel 80: 565-574.

17. Hansen AC, Mendoza M, Zhang Q, Reid JF (2000) Evaluation of oxydiesel as a fuel for direct-injection compression-ignition.

18. Turner J, Pearson R, Holland B, Peck R (2007) Alcohol-based fuels in high performance engines. SAE Technical Paper 2007-01-0056.

19. Roig A, Cayuela ML, Sánchez-Monedero MA (2006) An overview on olive mill wastes and their valorisation methods. Waste Manag 26: 960-969. 